\title{
Anti-HIF-1alpha LNA Antisense Oligonucleotide EZN-2968
}

National Cancer Institute

\section{Source}

National Cancer Institute. Anti-HIF-1alpha LNA Antisense Oligonucleotide EZN-2968. NCI

Thesaurus. Code C68930.

A synthetic antisense oligodeoxynucleotide (AS ODN) targeting hypoxia-inducible factor1alpha (HIF-1alpha) with potential antineoplastic activity. Anti-HIF-1alpha LNA antisense oligonucleotide EZN-2968 hybridizes with HIF-1alpha mRNA and blocks t HIF-1 alpha protein expression, which may result in the inhibition of angiogenesis, the inhibition of tumor cell proliferation, and apoptosis. HIF-1alpha, normally activated in response to hypoxia-induced stress, is a key transcription regulator of a large number of genes important in cellular adaptation to low-oxygen conditions, including angiogenesis, cell proliferation, apoptosis, and cell invasion. 